\title{
SOSIALISASI KEBIJAKAN PENGHAPUSAN HUMAN TRAFFICKING \\ DI KABUPATEN INDRAMAYU
}

\author{
Slamet Mulyana, Meria Octavianti, Atwar Bajari \\ Fakultas IImu Komunikasi Universitas Padjadjaran \\ Email : mulyanaslamet@yahoo.com ; meria.octavianti@unpad.ac.id ; \\ abahzeinius@gmail.com
}

\begin{abstract}
ABSTRAK
Human trafficking merupakan salah satu isu strategis dalam upaya pemberdayaan perempuan, yang menjadi perhatian serius pemerintah baik di tingkat pusat maupun pemerintah daerah provinsi serta kabupaten/kota di Indonesia. Peraturan daerah yang berisi kebijakan mengenai penghapusan human trafficking pertama kali disusun di Kabupaten Indramayu, yang notabene merupakan daerah dengan tingkat human trafficking yang tinggi di Indonesia. Kebijakan yang baik adalah kebijakan yang diketahui, dipahami, dan diimplementasikan oleh masyarakat yang menjadi sasarannya. Diperlukan penyusunan strategi komunikasi yang tepat agar apa yang menjadi tujuan dari kebijakan tersebut dapat tercapai. Oleh karena itu, penelitian ini bermaksud untuk mengungkap mengenai strategi komunikasi yang dilakukan dalam sosialisasi kebijakan penghapusan human trafficking di Kabupaten Indramayu, yang terdiri dari strategi komunikator, strategi pesan dan khalayak, serta strategi media.

Metode penelitian yang digunakan dalam penelitian ini adalah metode kualitatif dengan pendektatan studi kasus. Aparat Pemerintah Daerah Kabupaten Indramayu yang dipilih secara purposif merupakan subjek dalam penelitian ini, sedangkan objek penelitiannya adalah strategi komunikasi dalam sosiallisasi kebijakan penghapusan human trafficking. Pengumpulan data dilakukan dengan melakukan wawancara mendalam, observasi partisipatif, dan studi literatur.

Hasil penelitian menunjukkan bahwa terdapat lima pertimbangan yang menjadi dasar penyusunan strategi komunikasi yaitu karakteristik masyarakat kelompok sasaran, tujuan yang ingin dicapai, aturan perundangan-undangan yang berlaku, tugas pokok dan fungsi SKPD, serta ketersediaan anggaran. Atas pertimbangan kelima hal tersebut maka disusunlah sebuah strategi komunikasi yang terdiri dari strategi komunikator, strategi pesan dan khalayak, serta strategi media. Komunikator dalam sosialisasi adalah Satuan Tugas Anti Human Trafficking yang terdiri dari berbagai unsur yang bekerja sesuai dengan bidang yang ditanganinya dan jenis informasi yang disampaikan. Informasi yang disampaikan berupa delapan topik pesan yang disusun dalam bentuk pemaparan dan
\end{abstract}


bahasa yang menarik, yang disesuaikan dengan kemampuan penerimaan masing-masing kelompok sasaran. Selain menggunakan media sebar seperti poster, brosur, flyers, leaflet, dan lainnya, pelatihan dan penyuluhan juga menjadi media yang digunakan dalam sosialisasi kebijakan penghapusan human trafficking di Kabupaten Indramayu.

\section{ABSTRACT}

Human trafficking is one of the strategic issues in the empowerment of women, which is a serious concern of government at both the central and provincial government and district / city in Indonesia. Local regulation which containing policies on the elimination of human trafficking was first conceived in Indramayu, which in fact is the area with high levels of human trafficking in Indonesia. A good policy is a policy that is known, understood, and implemented by the communities. Therefore, this research will be known about communication strategy about the human trafficking ellimination in Indramayu.

Qualitative research with case study method used in this research. Research subject is Indramayu District Government officials who selected purposivelya and research subject is communication strategy about the human trafficking ellimination in Indramayu. Data were collected through interviews, pastisipative observation, and literature study.

The result of this research shows that there are five considerations that form the basis of the communication strategy: audience characteristic, the purpose, legislation rules, "tupoksi" SKPD, and the availability of budget. Communication strategy is based on five considerations, there are communicator strategy, message and audience startegy, and media strategy.

\section{PENDAHULUAN}

Human trafficking merupakan salah satu isu strategis dalam upaya pemberdayaan perempuan, yang menjadi perhatian serius pemerintah baik di tingkat pusat maupun pemerintah daerah provinsi serta kabupaten/kota. Pemerintah daerah Kabupaten Indramayu, sebagai sebuah wilayah dengan angka human trafficking yang tinggi di Jawa Barat, sudah merespon isu tersebut sejak lama, dengan diterbitkannya Perda Indramayu No. 14 tahun 2005 tentang Pencegahan dan Pelarangan Human Trafficking untuk Eksploitasi Seksual Komersial Anak (ESKA). Indramayu adalah kabupaten yang pertama di seluruh Indonesia yang menerbitkan Peraturan Daerah Anti Human Trafficking. 
Perda Anti Human Trafficking menjadi 'payung hukum' bagi Pemerintah Daerah dalam melakukan langkah-langkah nyata untuk menangani dan menyelesaikan masalah human trafiking di Kabupaten Indramayu. Kegiatan sosialisasi merupakan salah satu aktivitas yang dilakukan, setelah sebelumnya dibentuk Tim Satuan Tugas Anti Human Trafficking yang melibatkan berbagai unsur aparat pemerintah, perguruan tinggi, serta LSM/Ormas. Satuan Tugas Anti Human Trafficking merupakan pihak yang bertanggung jawab sepenuhnya terhadap perencanaan, pelaksanaan maupun evaluasi dan monitoring penghapusan human traficking di Indramayu.

Sosialisasi kebijakan penghapusan human trafficking merupakan langkah awal yang dilakukan Satuan Tugas Anti Human Trafficking, sebagai bagian dari upaya preventif untuk mencegah sedini mungkin terjadinya kasus Human Trafficking. Dalam hal ini, agar kegiatan sosialisasi berjalan optimal dibutuhkan pendekatan-pendekatan komunikasi yang relevan dengan situasi dan kondisi lokal.

Perumusan strategi komunikasi dibicarakan dalam beberapa kali pertemuan formal yang melibatkan seluruh SKPD dan komponen masyarakat yang tergabung dalam Satuan Tugas Anti Trafiking. Pembahasan awal menyangkut kejelasan peran dan tanggung jawab masing-masing pihak sesuai dengan masing-masing bidang dalam satuan tugas. Hal ini penting agar tidak ada tumpang tindih peran dan tanggung jawab sehingga tercipta jejaring kemitraan yang kuat di antara pihak-pihak tersebut sehingga upaya sosialisasi yang akan dilakukan berjalan secara sinergis sesuai dengan tugas pokok dan fungsi masing-masing.

Upaya sosialisasi kebijakan penghapusan trafiking di Kabupaten Indramayu dilakukan sesuai dengan amanat yang ditegaskan dalam Perda Indramayu No 14 tahun 2005 tentang Pencegahan dan Pelarangan Trafiking untuk Eksploitasi Seksual Komersial Anak (ESKA). Upaya tersebut sejalan dengan Keppres No. 87 Tahun 2002 Tentang RAN Penghapusan Eksploitasi Seksual Komersial Anak, Keppres No. 88 Tahun 2002 tentang RAN Penghapusan Perdagangan (Trafiking) Perempuan dan Anak, Keppres tentang RAN Penghapusan Bentuk-Bentuk Pekerjaan Terburuk bagi Anak PP No. 6 Tahun 2006 tentang Penyelenggaraan Kerjasama dan Pemulihan, PP No 9 Tahun 2008 tentang Tata Cara dan Mekanisme Pelayanan Terpadu Bagi Saksi dan/atau Korban Tindak Pidana Perdagangan Orang, Perda Jawa Barat No. 5 Tahun 2006 Tentang Perlindungan Anak, Perda Jawa Barat No 3 Tahun 2008 tentang Pencegahan dan Penanganan Korban Perdagangan Orang di Jawa Barat, dan Undang-undang Republik Indonesia Nomor 21 Tahun 2007 tentang Pemberantasan Tindak Pidana Perdagangan Orang.

Sejumlah pihak mengatakan bahwa kegiatan sosialisasi merupakan hal penting yang harus dilakukan oleh pemerintah daerah untuk menangani masalah human 
trafficking di Kabupaten Indramayu, terutama untuk meningkatkan kesadaran warga terhadap bahaya yang ditimbulkan.

"Trafiking masih tetap marak di Indramayu sampai saat ini. Kami secara terus menerus berusaha melakukan berbagai upaya untuk mengatasi kejahatan trafiking, di antaranya dengan melakukan sosialisasi ke berbagai pihak"21

Sosialisasi kebijakan penghapusan human trafficking dilakukan dengan mengikuti prinsip-prinsip seperti adanya penghormatan dan pengakuan terhadap hak dan martabat manusia, kepastian hukum, proporsionalitas, non-diskriminasi, perlindungan, dan keadilan. Adapun tujuan dari sosialisasi ini adalah untuk (1) mencegah sejak dini perdagangan orang; (2) memberikan perlindungan terhadap orang dari eksploitasi dan perbudakan manusia; dan (3) menyelamatkan dan merehabilitasi korban perdagangan orang; dan (4) memberdayakan pendidikan dan perekonomian korban perdagangan orang beserta keluarganya.

Tujuan sosialiasi yang dilakukan akan dapat tercapai apabila disusun sebuah strategi yang tepat dalam mengkomunikasi kebijakan tersebut. Sebaik-baiknya sebuah kebijakan adalah yang diketahui, dipahami dan diimplementasikan oleh target sasarannya. Oleh karena itu, penelitian ini berusaha untuk mengungkap mengenai strategi komunikasi yang dilakukan dalam sosialisasi kebijakan penghapusan human trafficking di Kabupaten Indramayu, yang terdiri dari strategi komunikator, strategi pesan dan khalayak, serta strategi media.

\section{TINJAUAN PUSTAKA}

\section{Tinjauan mengenai Sosialisasi}

Sosialisasi, menurut Effendy (1999: 27) adalah penyediaan sumber ilmu pengetahuan yang memungkinkan orang bersikap dan bertindak sebagi anggota masyarakat yang efektif yang menyebabkan ia sadar akan fungsi sosialnya sehingga ia dapat aktif di dalam masyarakat. Proses sosialisasi ini terjadi melalui interaksi sosial, yaitu hubungan antar- manusia yang menghasilkan suatu proses pengaruh-mempengaruhi (Susanto, 1999: 13). Suatu interaksi sosial tidak akan mungkin terjadi apabila tidak memenuhi dua syarat, yaitu: (1) kontak sosial dan (2) komunikasi. Oleh karenanya, di dalam proses sosialisasi selalu terjadi proses komunikasi (Soekanto, 1999: 71)

Komunikasi yang berkaitan dengan proses sosialisasi adalah komunikasi sosial. Komunikasi sosial merupakan suatu proses sosialisasi untuk menciptakan pencapaian stabilitas sosial, tertib sosial, penerusan nilai-nilai lama dan baru yang diagungkan oleh

${ }^{21}$ Wawancara Iwa Sungkawa, 10 Agustus 2009 
suatu masyarakat dipupuk, dibina dan diperluas. Melalui komunikasi sosial, masalahmasalah sosial dipecahkan melalui konsensus (Bungin, 2006: 32).

Tak jarang pula sosialisasi dilakukan untuk memperkenalkan gagasan-gagasan kepada masyarakat dengan asumsi bahwa masyarakat tersebut tidak mengetahui gagasan tersebut secara pasti. Kebaruan suatu ide atau gagasan tidaklah selamanya benar-benar baru, melainkan hanya karena dianggap baru oleh penerima (Arifin, 1994: 10).

Effendy (1999: 21) mengatakan komunikasi pada hakikatnya adalah proses penyampaian pikiran,atau perencanaan atau perasaan oleh seseorang (komunikator) kepada orang lain (komunikan). Pikiran bisa merupakan gagasan, informasi, opini dan lain-lain yang muncul dari benaknya. Perasaan bisa berupa keyakinan, kepastian, keraguan, kekhawatiran, kemarahan keberanian, kegairahan dan sebagainya yang timbul dari lubuk hati (Bungin, 2006: 31).

Menurut Effendy (1999: 32), strategi komunikasi merupakan panduan perencanaan komunikasi (communication planning) dengan manajemen komunikasi (communication management) untuk mencapai tujuan yang telah ditetapkan. Strategi komunikasi ini harus mampu menunjukan bagaimana operasionalnya secara praktis harus dilakukan, dalam arti kata bahwa pendekatan (approach) bisa berbeda-beda bergantung pada situasi dan kondisi. Sedangkan Arifin (1994: 10) mendefinisikan strategi komunikasi sebagai suatu perencanaan komunikasi yang meliputi strategi dan manajemen perencanaan strategi menyangkut tindakan apa yang dilakukan, sedangkan perencanaan meliputi bagaimana hal-hal itu terjadi.

Perubahan merupakan hasil proses komunikasi yang tidak mungkin dielakan. Semua pihak berkomunikasi, mau tidak pasti mengalami perubahan, baik perubahan kecil maupun perubahan besar. Bahkan komunikasi dapat merubah sama sekali citra seseorang atau kelompok mengenai dirinya sendiri maupun mengenai lingkungannya. Itulah sebabnya komunikasi memiliki kedudukan yang sangat strategis dalam keseluruhan perubahan masyarakat atau perubahan sosial (Arifin, 1994: 10). Strategi komunikasi digunakan tidak cukup hanya dalam tahap kesadaran (awareness), tetapi bagi tahap-tahap komunikasi lainnya, yaitu perubahan sikap (attitude change) dan perubahan perilaku (behaviour changes) pada seseorang atau lebih individu (Kennedy, 2006: 57).

\section{Strategi Komunikasi}

Secara umum, strategi diartikan sebagai perencanaan tindakan yang disusun berdasarkan tujuan dan kebijakan untuk mencapai tujuan itu sendiri. James Brian Quin, 
dalam bukunya yang berjudul Strategies For Change: Logical Incrementalism, seperti dikutip Grant, memberikan definis strategi berikut ini:

"Strategi merupakan suatu bentuk atau rencana yang mengintegrasikan tugastugas utama, kebijakan-kebijakan dan rangkaian tindakan dalam suatu organisasi menjadi suatu kesatuan yang utuh. Strategi yang diformulasikan dengan baik akan membantu penyusunan dan pengalokasian sumber daya yang dimiliki perusahaan menjadi suatu bentuk yang unik dan dapat bertahan. Strategi yang baik disusun berdasarkan kemampuan internal dan kelemahan perusahaan, antisipasi perubahan dalam lingkungan, serta kesatuan pergerakan yang dilakukan oleh mata-mata musuh" (Grant, 1999 : 10).

Effendy (1999: 21) mengatakan komunikasi pada hakikatnya adalah proses penyampaian pikiranatau perencanaan atau perasaan oleh seseorang (komunikator) kepada orang lain (komunikan). Pikiran bisa merupakan gagasan, informasi, opini dan lain-lain yang muncul dari benaknya. Perasaan bisa berupa keyakinan, kepastian, keraguan, kekhawatiran, kemaraha, keberanian, kegairahan dan sebagainya yang timbul dari lubuk hati (Bungin, 2006: 31).

Menurut Effendy (1999: 32), strategi komunikasi merupakan panduan perencanaan komunikasi (communication planning) dengan manajemen komunikasi (communication management) untuk mencapai tujuan yang telah ditetapkan. Strategi komunikasi ini harus mampu menunjukan bagaimana operasionalnya secara praktis harus dilakukan, dalam arti kata bahwa pendekatan (approach) bisa berbeda-beda bergantung pada situasi dan kondisi. Sedangkan Arifin (1994: 10) mendefinisikan strategi komunikasi sebagai suatu perencanaan komunikasi yang meliputi strategi dan manajemen perencanaan strategi menyangkut tindakan apa yang dilakukan, sedangkan perencanaan meliputi bagaimana hal-hal itu terjadi.

Menyusun strategi komunikasi tidaklah mudah dikarenakan aktivitas komunikasi yang sangat kompleks. Banyak faktor yang harus diperhatikan dalam membuat strategi komunikasi, diantaranya adalah komponen-komponen dari aktifitas itu sendiri. Harold D.Laswell mendefinisikan komunikasi dengan pertanyaan-pertanyaan yang spesifik dimana jawaban-jawabanya merupakan komponen-komponen yang ada dalam sebuah aktivitas komunikasi. Rumusan pertanyaan tersebut dikenal dengan istilah Paradigma Laswell, yakni terdiri dari : (1) Who? (siapakah komunikatornya?), (2) Says What? (pesan apa yang dinyatakanya?), (3) In which channel?( media apa yang digunakannya?) (4) To Whom? ( siapakah komunikannya ?), *5) With what effect?( efek apa yang diharapkan?) 
(Effendy, 2003: 301). Kelima hal tersebut adalah komponen dasar yang harus disusun dalam sebuah strategi komunikasi.

\section{METODE PENELITIAN}

Metode penelitian kualitatif dengan pendekatan studi kasus digunakan dalam penelitian mengenai sosialisasi kebijakan penghapusan human trafficking di Kabupaten Indramayu. Metode penelitian kualitatif digunakan dalam penelitian ini karena tujuan dari penelitian ini menghendaki adanya pernbahasan yang holistik, sistemik, dan mengungkapkan makna dibalik fakta empiris mengenai proses penyusunan strategi komunikasi dalam sosialisasi kebijakan penghapusan trafficking.

Pengumpulan data dilakukan melalui wawancara dengan beberapa narasumber terpilih, observasi langsung di lapangan, dan studi dokumentasi. Narasumber dalam penelitian ini adalah pimpinan Satuan Kerja Perangkat Daerah (SKPD) yang terlibat dalam penanganan human trafficking di Indramayu, Pimpinan Lembaga Swadaya Masyarakat (LSM) / Organisasi masyarakat (ormas), serta tokoh masyarakat. Data yang diperoleh diproses dan dianalisis melalui tahap-tahap: deskripsi, analisis tema, dan penonjolan.

Subjek dalam penelitian ini adalah aparatur Pemerintah Daerah Kabupaten Indramayu yang dipilih secara purposif dengan pertimbangan bahwa mereka adalah aparatur yang mengetahui dan mampu menjelaskan "bagaimana" dan "mengapa" tentang strategi komunikasi dalam sosialisasi kebijakan penghapusan human trafficking. Sedangkan yang menjadi objek dalam penelitian ini adalah strategi komunikasi yang diterapkan Pemerintah Daerah Kabupaten Indramayu dalam sosialisasi kebijakan penghapusan human trafficking.

\section{HASIL DAN PEMBAHASAN}

Penyusunan strategi komunikasi dalam upaya penghapusan human trafficking di Kabupaten Indramayu dilakukan dengan mempertimbangkan hal-hal substansial yang diperkirakan akan mempengaruhi pelaksanaan sosialisasi. Hal-hal tersebut menyangkut karakteristik masyarakat kelompok sasaran, tujuan yang ingin dicapai, aturan perundangan-undangan yang berlaku, tugas pokok dan fungsi SKPD, serta ketersediaan anggaran.

\section{Karakteristik masyarakat Indramayu sebagai kelompok sasaran}

Sasaran dari sosialisasi kebijakan penghapusan trafiking adalah seluruh lapisan masyarakat Indramayu, dengan prioritas adalah kelompok paling rentan yaitu perempuan dan anak-anak. Pemahaman terhadap karakteristik kelompok sasaran menjadi aspek penting untuk merumuskan pendekatan komunikasi yang relevan. Hal tersebut dilakukan 
Satuan Tugas Anti Human Trafficking ketika mempertimbangkan kondisi-kondisi eksternal yang mempengaruhi maraknya kasus human trafficking, yang mencakup tingkat kemiskinan yang tinggi; budaya masyarakat yang kontraproduktif seperti budaya luruh duit dan budaya konsumtif; tingkat pendidikan yang rendah; serta perkawinan dini dan tingkat perceraian yang tinggi.

Kelompok sasaran dalam sosialisasi diklasifikasikan sesuai dengan bentuk kegiatan yang akan dilakukan. Kelompok-kelompok tersebut antara lain kalangan pelajar dari mulai Sekolah Dasar sampai Sekolah Menengah Atas, kelompok ibu rumah tangga, ibuibu pengajian, pengurus PKK, kelompok pengurus LSM/Ormas, pengelola penyalur jasa TKI (PJTKI).

\section{Visi dan Misi Indramayu sebagai tujuan}

Tujuan akhir dari kebijakan penghapusan human trafficking, termasuk di dalamnya kegiatan sosialisasi, adalah mewujudkan visi dan misi Kabupaten Indramayu yang secara singkat tercermin dari visi 'Indramayu Remaja' (Religius, Maju, Mandiri, dan Sejahtera). Sementara misi Indramayu yang berkaitan dengan masalah human trafficking adalah misi pertama yaitu peningkatan kualitas sumberdaya manusia. Untuk mewujudkan visi dan misi tersebut, khususnya visi religius dan sejahtera serta misi peningkatan kualitas sumberdaya manusia, dibutuhkan pendekatan komunikasi dalam proses sosialisasi, yang mampu meningkatkan kesadaran masyarakat sehingga mampu mencegah sedini mungkin bahaya trafficking.

“Kegiatan yang kami lakukan sebagai bagian dari unsur SKPD, dan juga sekarang bagian dari Satgas, jelas harus mendukung pencapaian visi dan misi Indramayu. Itu sudah menjadi komitmen kita semua! Kantor Pemberdayaan Perempuan dan KB berupaya mewujudkan itu kepada kelompok sasaran kami yaitu kalangan perempuan." 22

\section{Aturan perundang-undangan sebagai Landasan Hukum}

Penyusunan strategi komunikasi dalam sosialisasi kebijakan penghapusan human trafficking mempertimbangkan berbagai aturan yang relevan dengan masalah trafficking dan yang berlaku baik di tingkat pusat, tingkat provinsi maupun tingkat kabupaten/kota. Pembahasan tentang aturan perundang-undangan ini merupakan bagian tugas dan tanggung jawab Bidang III Penegakan Hukum dari Satuan Tugas Anti Human Trafficking.

Aturan perundang-undangan yang menjadi acuan dalam penyusunan strategi komunikasi dalam sosialisasi kebijakan penghapusan human trafficking antara lain (1) Keppres No. 87 Tahun 2002 Tentang RAN Penghapusan Eksploitasi Seksual Komersial

${ }^{22}$ Wawancara Edi Kusdiana, 19 Oktober 2009 
Anak, (2) Keppres No. 88 Tahun 2002 tentang RAN Penghapusan Perdagangan (Trafficking) Perempuan dan Anak, (3) Keppres tentang RAN Penghapusan Bentuk-Bentuk Pekerjaan Terburuk bagi Anak PP No. 6 Tahun 2006 tentang Penyelenggaraan Kerjasama dan Pemulihan, (4) PP No 9 Tahun 2008 tentang Tata Cara dan Mekanisme Pelayanan Terpadu Bagi Saksi dan/atau Korban Tindak Pidana Perdagangan Orang, Perda Jawa Barat No. 5 Tahun 2006 Tentang Perlindungan Anak, (5) Perda Jawa Barat No 3 Tahun 2008 tentang Pencegahan dan Penanganan Korban Perdagangan Orang di Jawa Barat, dan (6) Undang-undang Republik Indonesia Nomor 21 Tahun 2007 tentang Pemberantasan Tindak Pidana Perdagangan Orang

\section{Tugas pokok dan fungsi SKPD}

Masing-masing SKPD yang tergabung dalam Satuan Tugas Anti Human Trafficking mempunyai tugas pokok dan fungsi masing-masing sesuai dengan nomenklatur kelembagaan pemerintah di Kabupaten Indramayu. Penempatan masingmasing SKPD dalam bidang-bidang yang ada di dalam Satuan Tugas Anti Human Trafficking sebenarnya sudah mempertimbangkan tugas pokok dan fungsi tersebut. Penyusunan strategi komunikasi dalam sosialisasi kebijakan penghapusan trafiking juga perlu mempertimbangkan hal tersebut, sehingga masing-masing SKPD juga bisa berperan sebagai sumber yang memiliki kredibilitas yang bisas dipertanggungjawabkan

\section{Ketersediaan Anggaran}

Dalam Surat Keputusan Bupati Indramayu tentang Pembentukan Satuan Tugas Anti Human Trafficking jelas disebutkan bahwa segala implikasi pembiayaan dari diterbitkannya surat keputusan tersebut dibebankan kepada Anggaran Pendapatan dan Belanja Daerah (APBD) Kabupaten Indramayu. Masalah anggaran seringkali menjadi masalah rumit dan perlu dibicarakan mengingat untuk membiayai segala kegiatan yang dilakukan Satgas dibutuhkan biaya yang sangat besar. Padahal di sisi lain, kemampuan pemerintah daerah juga terbatas dan banyak juga prioritas pembangunan lain yang juga membutuhkan pembiayaan dari pemerintah daerah. Dalam hal ini, penyusunan strategi komunikasi dalam sosialisasi kebijakan penghapusan Human Trafficking perlu mempertimbangkan besarnya alokasi anggaran yang tersedia. Hal ini penting sebagai acuan untuk menetapkan anggaran yang rasional dan bisa dipertanggungjawabkan. 


\section{Strategi Komunikasi dalam Sosisalisasi Kebijakan Anti Human Trafficking}

Strategi Komunikator

Sesuai dengan Surat Keputusan Bupati Indramayu No. 463.05/Kep.980Sosnaker/2006 dan lampirannya, Satuan Tugas Anti Human Trafficking adalah pihak yang paling bertanggung jawab untuk menangani dan menyelesaikan masalah human trafficking di Kabupaten Indramayu. Satuan Tugas ini bertanggung jawab dari mulai pencegahan dan penanganan kasus human trafficking sampai pada rehabilitasi korban.

Dalam kegiatan sosialisasi, semua pihak yang tergabung dalam Satuan Tugas Anti Human Trafficking adalah sumber yang akan menyampaikan pesan sosialisasi kepada kelompok sasaran yang akan ditetapkan berdasarkan prioritas. Sejalan dengan tugas pokok dan fungsi masing-masing pihak serta peran dan tanggung jawabnya dalam Satgas sesuai dengan bidangnya, maka masing-masing pihak dapat menyampaikan informasi berkenaan dengan masalah human trafficking kepada pihak luar atau kelompok sasaran.

Namun demikian, untuk kelancaran mekanisme kerja di dalam Satuan tugas, dilakukan koordinasi dan kerjasama di antara unsur-unsur Satgas sehingga informasi disampaikan oleh salah satu unsur anggota Satgas yang memiliki kompetensi yang memadai dalam bidang tersebut. Hal ini penting mengingat masyarakat sebagai kelompok sasaran membutuhkan informasi yang akurat dan cukup komprehensif, yang disampaikan oleh sumber-sumber yang menurut mereka bisa dipercaya dan memahami apa yang disampaikannya.

Dalam hal ini, tugas Ketua Umum dan Ketua Harian Satuan Tugas Anti Human Trafficking beserta wakilnya adalah mengkoordinasikan kegiatan yang dilakukan masingmasing unsur yang tergabung di dalam Satgas. Selain itu, dalam berbagai kesempatan atau pertemuan resmi Ketua Umum dan atau Ketua Harian berperan sebagai juru bicara (spoke person) Satgas, khususnya untuk informasi-informasi umum yang menyangkut aktivitas yang dilakukan Satgas. Sedangkan sekretaris dan wakilnya bertanggung jawab untuk pengelolaan administrasi dan melakukan koordinasi berkaitan dengan berbagai aktivitas yang dijalankan seluruh anggota Satgas. Sementara bendahara dan wakilnya bertanggung jawab untuk mengelola anggaran yang digunakan dalam membiayai segala aktivitas yang dijalankan Satgas.

Gambaran tentang bidang kerja Satuan Tugas Anti Human Trafficking dan peran masing-masing sebagai sumber informasi dan jenis informasi yang disampaikan dapat dilihat pada Tabel 1 
Tabel 1

Bidang Satuan Tugas dan Jenis Informasi yang Disampaikan

\begin{tabular}{|c|c|c|}
\hline $\begin{array}{c}\text { Bidang } \\
\text { yang ditangani }\end{array}$ & $\begin{array}{c}\text { Unsur Satgas sebagai } \\
\text { Sumber Informasi }\end{array}$ & $\begin{array}{c}\text { Jenis informasi } \\
\text { yang disampaikan }\end{array}$ \\
\hline $\begin{array}{l}\text { Pencegahan segala } \\
\text { bentuk human } \\
\text { trafficking }\end{array}$ & $\begin{array}{l}\text { Dinas Tramtib, Subdin Ketahan } \\
\text { Masyarakat Desa, Subdin } \\
\text { Penempatan Tenaga Kerja dan } \\
\text { Perluasan Kerja, Subdin Keluarga } \\
\text { Sejahtera, Seksi Pengawasan Norma } \\
\text { Kerja dan Jaminan Sosial Tenaga } \\
\text { Kerja, Tim Penggerak PKK, LSM } \\
\text { Papuan, LSM FKBMI }\end{array}$ & $\begin{array}{l}\text { - } \text { Bahaya human trafficking } \\
\text { - dan Buruh migran } \\
\text { - Human trafficking dan Pelacuran } \\
\text { - Pendidikan Keluarga } \\
\text { - Pendidikan Masyarakat }\end{array}$ \\
\hline $\begin{array}{l}\text { Kerjasama dan } \\
\text { Koordinasi }\end{array}$ & $\begin{array}{l}\text { Bappeda, Komisi B DPRD, Bidang } \\
\text { Sosial Budaya Bappeda, } \\
\text { Subbag Pemberdayaan perempuan, } \\
\text { MUI, LPPM Unwir }\end{array}$ & $\begin{array}{l}\text { - } \text { Bahaya human trafficking } \\
\text { - Human dan Perempuan } \\
\text { - Human trafficking dan Agama } \\
\text { - Jejaring human trafficking } \\
\text { - Kerjasama untuk Penanganan } \\
\quad \text { human trafficking }\end{array}$ \\
\hline Penegakan Hukum & $\begin{array}{l}\text { Bagian Hukum Setda, Subdin } \\
\text { Hubungan Industrial dan } \\
\text { Pengawasan Ketenagakerjaan, Seksi } \\
\text { Teritorial Kodim 0616, Pengadilan } \\
\text { Negeri, Subdin Polisi Pamong } \\
\text { Praja, Satuan Reserse (Polisi), Seksi } \\
\text { Tindak Pidana Khusus, LBH Unwir, } \\
\text { IKADIN }\end{array}$ & $\begin{array}{l}\text { - } \text { Bahaya human trafficking } \\
\text { trafficking } \\
\text { - Pengawasan Buruh Migran } \\
\text { - Penanganan Pelaku human } \\
\text { trafficking } \\
\text { - Bantuan Hukum Korban human } \\
\text { trafficking }\end{array}$ \\
\hline $\begin{array}{l}\text { Rehabilitasi dan } \\
\text { reintegrasi }\end{array}$ & $\begin{array}{l}\text { Dinas Kesehatan, Subdin pendidikan } \\
\text { Masyarakat, Seksi Pendidikan } \\
\text { Keagamaan Masyarakat, Seksi } \\
\text { Kesejahteraan Keluarga dan Jompo, } \\
\text { Seksi Pelayanan FKPP, LSM As- } \\
\text { Sakienah, LSM YPI }\end{array}$ & $\begin{array}{l}\text { - } \text { Bahaya human trafficking } \\
\text { Penanganan Korban human } \\
\text { - Pemulficking } \\
\text { trafficking } \\
\text { - Pengelolaan Shelter dan Trauma } \\
\text { Center } \\
\text { - Pendidikan keluarga dan } \\
\text { masyarakat }\end{array}$ \\
\hline
\end{tabular}

Sumber: Pengolahan Data Penelitian, 2009 
Berdasarkan data pada pada Tabel 1 dapat dikemukakan bahwa masing-masing unsur yang tergabung dalam Satuan Tugas Anti Human Trafficking menempati bidang garapan yang spesifik dan mempunyai tugas dan kewajiban yang berbeda berkaitan dengan jenis informasi yang disampaikannya. Dasar pertimbangannya adalah agar peran masing-masing pihak sebagai sumber informasi dapat dijalankan dengan sebaik-baiknya. Selain itu, dengan pembagian tugas seperti itu kemungkinan terjadinya tumpang tindih informasi yang disampaikan dapat diminimalisir atau dikurangi. Walaupun demikian, informasi yang bersifat umum seprti informasi tentang bahaya human trafficking menjadi tanggung jawab semua pihak di dalam Satuan Tugas Anti Human Trafficking.

\section{Strategi Pesan dan Strategi Khalayak}

Sosialisasi kebijakan penghapusan human trafficking merupakan salah satu langkah preventif untuk mencegah terjadinya kasus-kasus human trafficking. Upaya preventif diarahkan untuk mencegah terjadinya kasus human trafficking dengan membangun supporting system yang mampu memberikan peringatan dini terhadap kemungkinan terjadinya kasus human trafficking. Hal itu bisa dilakukan jika masyarakat memiliki kesadaran yang memadai tentang bahaya dari human trafficking.

Kesadaran masyarakat akan tumbuh dengan baik jika mereka mendapatkan informasi yang lengkap dan akurat tentang human trafficking dengan berbagai aspek di dalamnya dari pihak-pihak yang memahami masalah tersebut. Di sisi lain, penerimaan dan pemahaman masyarakat terhadap berbagai informasi yang disampaikan sangat berkaitan dengan tingkat pendidikan, nilai-nilai dan norma-norma yang diyakini, serta situasi dan kondisi lingkungan. Di Kabupaten Indramayu, kedua kondisi ini saling bertentangan dan hal itu menjadi kendala besar dalam pelaksanaan sosialisasi human trafficking.

"Kami menyadari bahwa karakteristik masyarakat di sini memang beda. Ada halhal mendasar yang menjadi kendala buat instansi kami ketika bicara tentang trafficking. Informasi trafficking seringkali dipahami berbeda karena mereka menganggap menjadi buruh migrant atau bahkan menjadi PSK itu bukan masalah. Kalaupun mengalami nasib buruk, itu hanyalah takdir."23

Kendala tersebut menjadi tantangan yang harus disikapi dengan baik dan menjadi bahan pertimbangan untuk penyusunan strategi komunikasi dalam sosialisasi human trafficking, khususnya berkaitan dengan penyusunan pesan yang akan disampaikan.

\footnotetext{
${ }^{23}$ Wawancara Erpin Marpinda, 19 Oktober 2009
} 
Dalam hal ini, Satuan Tugas Anti Human Trafficking menyepakati untuk membagi dan mengklasifikasikan masyarakat kelompok sasaran sehingga lebih mudah mengidentifikasi karakteristik mereka.

"Tim satgas membicarakan kendala-kendala di lapangan khususnya tentang informasi yang akan disampaikan. Kami tahu, pesan itu akan diterima mereka kalau sesuai dengan kebutuhan mereka. Agar lebih mudah, kami sepakat, harus ada pembagian kelompok masyarakat. ${ }^{24}$

Dalam kegiatan sosialisasi kebijakan penghapusan human trafficking, sasarannya adalah seluruh lapisan masyarakat Kabupaten Indramayu. Berdasarkan skala prioritas kemudian ditentukan kelompok masyarakat yang menjadi fokus sasaran kegiatan sosialisasi, yaitu kelompok yang paling peka dan rentan terhadap masalah. Di Kabupaten Indramayu, kelompok yang paling rentah adalah perempuan muda usia 14-18 tahun, terutama dari keluarga miskin. Dengan pertimbangan tersebut kelompok sasaran adalah keluarga dengan anak yang masih gadis, sekolah- sekolah dari mulai Sekolah Dasar sampai Sekolah Lanjutan Atas, dan Kelompok Organisasi Perempuan seperti Ibu-ibu PKK, kelompok arisan, ataupun kelompok pengajian ibu-ibu. Setelah itu baru ditentukan kelompok lain di masyarakat yang akan menjadi sasaran kegiatan sosialisasi, di antaranya adalah pengelola LSM/Ormas, pengelola PJTKI, aparat pemerintah serta tokoh-tokoh masyarakat terutama di tingat desa.

Pemahaman sebagian besar masyarakat Indramayu tentang masalah human trafficking juga masih terbatas. Mereka tidak mengetahui dengan pasti apa yang dimaksud dengan human trafficking atau bagaimana kasus human trafficking terjadi. Mereka hanya tahu bahwa seeorang yang bekerja di luar negeri dan belum pernah mengirim uang ke kampung, itu menandakan mereka mendapat masalah di sana.

"Saya pernah memberikan materi pada satu pelatihan dengan peserta ibu-ibu PKK. Ketika saya tanya beberapa peserta tentang apa itu trafficking, jawaban mereka tidak ada yang benar. Pengetahuan dan pemahaman mereka tentang trafficking memang masih sangat terbatas"25

Beberapa topik atau tema yang disampaikan Satuan Tugas Anti Human Trafficking dalam sosialisasi human trafficking antara lain adalah (1) apa itu human trafficking, (2) mengenal trafficking in person, (3) modus operandi dalam human trafficking, (3) prosedur hukum dan rekruitmen tenaga kerja ke luar negeri, (4) human trafficking dalam

\footnotetext{
${ }^{24}$ Wawancara Edi Kusdiana, 19 Oktober 2009

${ }^{25}$ Ibid
} 
perspektif gender, (5) human trafficking dalam perspektif agama, (6) implikasi human trafficking dalam kesehatan (HIV/AIDS), (7) human trafficking dalam perspektif budaya, (8) human trafficking dan pelacuran. Tema yang lain juga disampaikan seperti (1) analisis situasi human trafficking di Indramayu, (2) peran civil society dalam menanggulangi human trafficking, (3) membangun jaringan kerjasama anti human trafficking dan diakhiri dengan pembuatan rencana tindak lanjut penanganan human trafficking.

Dalam pelaksanaannya di lapangan, topik-topik tersebut disusun lebih jauh dalam bentuk pemaparan dan bahasa penyampaian yang menarik, yang disesuaikan dengan kemampuan penerimaan masing-masing kelompok sasaran. Dengan cara demikian diharapkan pesan yang disampaikan dapat diterima dengan baik dan memperoleh hasil yang optimal.

\section{Strategi Media}

Sosialisasi kebijakan penghapusan human trafficking di Kabupaten Indramayu dilakukan melalui berbagai bentuk kegiatan dan menggunakan berbagai media komunikasi. Penggunaan media dan pendekatan komunikasi serta penentuan bentuk kegiatan yang dilakukan disesuaikan dengan karakteristik kelompok sasaran, dengan mempertimbangkan situasi dan kondisi wilayah di mana kelompok sasaran tersebut berada.

Bentuk-bentuk kegiatan yang dilakukan antara lain penyuluhan dan pelatihan. Kedua bentuk kegiatan dimaksudkan untuk membangun kesadaran, pengetahuan, dan keterampilan masyarakat tentang pencegahan human trafficking dan eksploitasi perempuan, serta membangun semacam pusat informasi untuk pencegahan dan penanganan trafficking perempuan dan anak. Hal tersebut dipilih berdasarkan pertimbangan perlunya kepedulian untuk memperkuat kapasitas masyarakat dalam upaya memerangi human trafficking.

"Dalam sosialisasi, kami memberikan penyuluhan atau pelatihan terhadap masyarakat. Diharapkan masyarakat mulai sadar dan paham bahaya trafficking dan bersama pemerintah berusaha mengatasinya, khusus di wilayah masingmasing." 26

Melalui penyuluhan dan pelatihan, masyarakat diharapkan mendapatkan pemahaman yang cukup komprehensif mengenai apa itu human trafficking, gender, bagaimana human trafficking dan eksploitasi terjadi, siapa pelaku human trafficking,

\footnotetext{
${ }^{26}$ Wawancara Ari Nurjaman, 5 Oktober 2009
} 
faktor pendorong dan penarik terjadinya human trafficking, serta apa yang bisa dilakukan untuk mencegah human trafficking. Pemahaman mengenai hal tersebut cukup penting, mengingat tidak semua masyarakat mengetahui mengenai informasi yang benar dan menyeluruh mengenai human trafficking.

Penyuluhan dan pelatihan dilakukan dengan menggunakan pendekatan komunikasi kelompok, yang dapat merangsang dan memotivasi masyarakat sebagai peserta untuk berpartisipasi aktif dalam proses tersebut. Peserta diajak untuk memetakan kondisi daerahnya untuk melihat bagaimana human trafficking yang terjadi di daerahnya, serta potensi di daerahnya yang dapat digunakan sebagai media pencegahan human trafficking. Hal ini dilakukan dengan pertimbangan bahwa proses sosialisasi yang baik harus dilakukan dengan melihat konteks lokal serta potensi lokal yang ada.

"Pendekatan kelompok tampaknya paling cocok dan mudah dilaksanakan. Kami bisa menyampaikan informasi pada sekelompok orang, yang terpilih. Dengan begitu penyampaiannya lebih mudah. Apalagi kalau para pesertanya aktif, kami akan lebih senang lagi." 27

Dalam pelaksanaannya di lapangan, kegiatan sosialisasi antara lain dilakukan dengan membuat paguyuban/kelompok di daerah masing-masing peserta, yang akan secara aktif mengkampanyekan tentang bahaya human trafficking. Aktivitas yang dilakukan dengan menggunakan potensi-potensi yang telah ada di masing-masing wilayah, misalnya pengajian, arisan, kelompok ibu-ibu PKK, radio komunitas, dan sebagainya.

Selain itu, pendekatan komunikasi kelompok yang lain yang digunakan dalam pelaksanaan sosialisasi kebijakan penghapusan human trafficking adalah focus group discussion (FGD). Pendekatan ini dimaksudkan untuk memperoleh pandangan lain tentang fenomena human trafficking dari masyarakat sehingga diperoleh gambaran yang semakin komprehensif tentang tarfiking di Indramayu. Dalam FGD, peserta yang terlibat diberikan kesempatan untuk saling berinteraksi mengungkapkan informasi yang mungkin masih tersebunyi tentang human trafficking dan peserta diberikan kesempatan untuk menyampaikan pemahaman dan wawasannya mengenai fenomena yang terjadi di masyarakat. FGD dilakukan jika peserta yang menjadi kelompok sasaran adalah pengelola LSM/Ormas yang peduli human trafficking atau aparat pemerintah yang ada di tingkat desa atau kecamatan.

Kegiatan komunikasi lain yang dilakukan dalam sosialisasi adalah penyebaran media sebar seperti poster, brosur, flyers, leaflet, dan lainnya. Berbagai media tersebut

${ }^{27}$ Wawancara, Erpin Marpinda, 19 Oktober 2009 
diberikan secara gratis kepada masyarakat, terutama kelompok sasaran prioritas, dalam berbagai kesempatan. Selain itu, media sebar seperti poster ditempelkan di beberapa lokasi strategis seperti di sekolah-sekolah, pesantren, atau papan-papan pengumuman lainnya.

Sosialisasi juga dilakukan dengan menggunakan media massa baik melalui radio ataupun melalui media cetak suratkabar. Kegiatan ini dilakukan untuk menyebarluaskan informasi-informasi tentang human trafficking dengan berbagai aspeknya, yang perlu diketahui oleh seluruh lapisan masyarakat di Kabupaten Indramayu. Dalam pelaksanaannya, Satuan Tugas Anti Human Trafficking bekerjasama dengan beberapa pengelola radio swasta dan radio komunitas yang ada di Kabupaten Indramayu. Sementara untuk media cetak, Satgas bekerjasama dengan pengelola surat kabar, seperti Indramayu Post, Radar Wilayah Cirebon, dan sebagainya.

Tabel 2

Jenis Pesan, Kelompok Sasaran, Bentuk Kegiatan dan

Pedekatan/Media Komunikasi dalam Sosialisasi Pengahapusan Human Trafficking

\begin{tabular}{|c|c|c|c|}
\hline $\begin{array}{l}\text { Jenis Pesan } \\
\text { yang Disampaikan }\end{array}$ & $\begin{array}{l}\text { Kelompok Sasaran } \\
\text { Prioritas }\end{array}$ & $\begin{array}{l}\text { Bentuk } \\
\text { Kegiatan } \\
\text { Utama }\end{array}$ & $\begin{array}{l}\text { Pendekatan/Media } \\
\text { Komunikasi }\end{array}$ \\
\hline Bahaya Trafiking & Seluruh masyarakat & $\begin{array}{l}\text { Penyebaran } \\
\text { informasi }\end{array}$ & $\begin{array}{l}\text { Media Massa, } \\
\text { Media sebar }\end{array}$ \\
\hline $\begin{array}{l}\text { Trafiking dan } \\
\text { Pelacuran }\end{array}$ & $\begin{array}{l}\text { Perempuan dan } \\
\text { Keluarga }\end{array}$ & $\begin{array}{l}\text { Pelatihan dan } \\
\text { Penyuluhan }\end{array}$ & Komunikasi Kelompok \\
\hline $\begin{array}{l}\text { Trafiking dan } \\
\text { Perempuan }\end{array}$ & Perempuan & $\begin{array}{l}\text { Pelatihan dan } \\
\text { Penyuluhan }\end{array}$ & Komunikasi Kelompok \\
\hline $\begin{array}{l}\text { Trafiking dan } \\
\text { Buruh migrant }\end{array}$ & $\begin{array}{l}\text { Pekerja dan Calon } \\
\text { pekerja Migran }\end{array}$ & $\begin{array}{l}\text { Pelatihan dan } \\
\text { Penyuluhan }\end{array}$ & Komunikasi Kelompok \\
\hline $\begin{array}{l}\text { Trafiking dan } \\
\text { Agama }\end{array}$ & $\begin{array}{l}\text { Tokoh Masyarakat } \\
\text { Keluarga }\end{array}$ & $\begin{array}{l}\text { Pelatihan dan } \\
\text { Penyuluhan } \\
\text { FGD }\end{array}$ & Komunikasi Kelompok \\
\hline $\begin{array}{l}\text { Landasan Hukum } \\
\text { Trafiking }\end{array}$ & $\begin{array}{l}\text { PJTKI, LSM } \\
\text { Aparat Pemerintah }\end{array}$ & $\begin{array}{l}\text { Pelatihan } \\
\text { FGD }\end{array}$ & Komunikasi Kelompok \\
\hline $\begin{array}{l}\text { Pencegahan dan } \\
\text { Penanganan } \\
\text { Korban Trafiking }\end{array}$ & $\begin{array}{l}\text { Aparat Pemerintah } \\
\text { LSM }\end{array}$ & $\begin{array}{l}\text { Pelatihan } \\
\text { FGD }\end{array}$ & Komunikasi Kelompok \\
\hline
\end{tabular}




\section{JURNAL MANAJEMEN KOMUNIKASI}

\begin{tabular}{|c|c|c|c|}
\hline $\begin{array}{l}\text { Pengelolaan } \\
\text { Shelter dan } \\
\text { Trauma Center }\end{array}$ & $\begin{array}{l}\text { Aparat Pemerintah } \\
\text { LSM }\end{array}$ & $\begin{array}{l}\text { Pelatihan } \\
\text { FGD }\end{array}$ & Komunikasi Kelompok \\
\hline $\begin{array}{l}\text { Pendidikan } \\
\text { Keluarga }\end{array}$ & Keluarga & $\begin{array}{l}\text { Pelatihan dan } \\
\text { Penyuluhan }\end{array}$ & Komunikasi Kelompok \\
\hline $\begin{array}{l}\text { Pendidikan } \\
\text { Masyarakat }\end{array}$ & $\begin{array}{l}\text { LSM } \\
\text { Tokoh masyarakat } \\
\text { Aparat pemerintah }\end{array}$ & $\begin{array}{l}\text { Pelatihan } \\
\text { FGD }\end{array}$ & Komunikasi Kelompok \\
\hline $\begin{array}{l}\text { Jejaring dan } \\
\text { Kerjasama } \\
\text { Penanganan } \\
\text { Trafiking }\end{array}$ & $\begin{array}{l}\text { Aparat pemerintah } \\
\text { LSM }\end{array}$ & $\begin{array}{l}\text { Pelatihan } \\
\text { FGD }\end{array}$ & Komunikasi Kelompok \\
\hline
\end{tabular}

Sumber: Pengolahan Data Penelitian, 2009

Gambaran mengenai jenis pesan yang disampaikan, kelompok sasaran yang menjadi prioritas, bentuk kegiatan utama yang dilakukan, dan pendekatan/ media komunikasi yang digunakan dalam sosialisasi kebijakan penghapusan human trafficking dapat dilihat pada Tabel 2. Berdasarkan data tersebut dapat dijelaskan bahwa pendekatan / media komunikasi yang digunakan dalam sosialisasi benar-benar dipertimbangkan oleh Satgas untuk disesuaikan dengan karakteristik kelompok sasaran yang menjadi prioritas dan bentuk kegiatan yang dilakukan. Pertimbangan ini dimaksudkan agar kegiatan sosialisasi bisa berjalan efektif dan memperoleh hasil yang optimal.

\section{KESIMPULAN}

Penyusunan strategi komunikasi dalam sosialisasi kebijakan penghapusan human trafficking di Kabupaten Indramayu didasarkan pada hasil analisis data situasi yang berupa karakteristik masyarakat kelompok sasaran, tujuan yang ingin dicapai, aturan perundangan-undangan yang berlaku, tugas pokok dan fungsi SKPD, serta ketersediaan anggaran. Kelima pertimbangan tersebut menjadi dasar penyusunan strategi komunikasi yang terdiri dari strategi komunikator, strategi pesan dan khalayak, serta strategi media.

Komunikator dalam sosialisasi penghapusan human trafficking di Kabupaten Indramayu adalah Satuan Tugas Anti Human Trafficking yang terdiri dari berbagai unsur yang bekerja sesuai dengan bidang yang ditanganinya dan jenis informasi yang disampaikan. Terdapat delapan topik pesan yang disampaikan dalam kegiatan sosialisasi, yang disusun dalam bentuk pemaparan dan bahasa yang menarik, yang disesuaikan 
dengan kemampuan penerimaan masing-masing kelompok sasaran. Selain menggunakan media sebar seperti poster, brosur, flyers, leaflet, dan lainnya, pelatihan dan penyuluhan juga menjadi media yang digunakan dalam sosialisasi kebiajakan penghapusan human trafficking di Kabupaten Indramayu.

\section{DAFTAR PUSTAKA}

Effendy, Onong Uchyana. 1999. Ilmu Komunikasi Teori dan Praktek. Bandung: Remaja. Rosdakarya.

Soekanto, Soerjono. 1989. Sosiologi Suatu Pengantar. Jakarta : Raja Grafindo Persada Bungin, Burhan.2007. Analisis Penelitian Kualitatif. Bandung : PT. Rajawali Pers.

Arifin, Anwar. 1994. Strategi Komunikasi. Bandung : CV Amrico. 